\title{
IMPACT OF REGIONAL OPERATIONAL PROGRAM FOR WIELKOPOLSKIE VOIVODESHIP 2007-2013 ON INNOVATION OF MICRO, SMALL AND MEDIUM ENTERPRISES IN WIELKOPOLSKA REGION
}

\section{MACIEJ CIEŚLUKOWSKI}

Poznań University of Economics, Faculty of Economics, POLAND

e-mail: m.cieslukowski@ue.poznan.pl

RECEIVED
ACCEPTED
JEL
CLASSIFICATION

KEYWORDS

ABSTRACT
18 January 2018

2 September 2018

$\mathrm{D} 22, \mathrm{H} 25, \mathrm{O} 31, \mathrm{O} 38$

EU funds, SME innovation, Regional Operational Program for Wielkopolskie Voivodeship, grants

The micro, small and medium enterprises (SMEs) sector is crucial for the development of an innovative and competitive European Union economy. In each programming period, the EU prepares a number of activities and tools for these companies to improve their market position. The article attempts to assess the impact of the Regional Operational Program for Wielkopolskie Voivodeship 2007-2013 (ROPW) on the innovation level of the SME sector in the region. The evaluation was based on 255 projects implemented by these companies within the ROPW. Research shows that there was little interest in EU funds from Wielkopolska entrepreneurs. However the examined projects were characterized by a high degree of innovation.

\section{Introduction}

Both in the 2010 Lisbon Strategy and in the current Europe 2020 Strategy, the European Union (EU) places particular emphasis on increasing the innovation of the SME sector. This sector is crucial for the development of an innovative and competitive economy. The European Commission reports that nearly 20.8 million of SMEs operate in the EU, employing 87.5 million people and creating added value of almost 3.5 bln euros (European Union, 
2014, p. 4). As a result, the European Union prepares a wide range of actions and tools for these companies to improve their market position in each programming period. The article attempts to assess the influence of Regional Operational Program for Wielkopolskie Voivodeship 2007-2013 (ROPW) on the level of SME sector innovation in the region. The assessment was made on the basis of an analysis of 255 investment projects implemented by SMEs under the program. It should be emphasized that the final report on the implementation of ROPW unfortunately gives fairly general data on the innovativeness of projects. It is limited to the total number of new and improved products across the range of activities and schemes, and the number of R\&D projects (Sprawozdanie WRPO..., 2017, pp. 266-274, załącz. IV, Tab. 4). The analysis of the projects allowed for a considerable refinement and supplementation of the indicated results.

\section{Litepature review}

The subject literature distinguishes the notions of innovation and innovativeness of the company. There are many definitions and types of innovation. Comprehensive review of these issues is given by Kraśnicka (2013) and Sikora and Uziębło (2013). In this article, innovations will be understood in broader terms, in line with the concept adopted by the OECD and Eurostat (Oslo Manual, 2005, pp. 48-58), as this approach has been applied in the SMEs projects under the ROPW. Innovation should be understood as the implementation of a new or significantly improved product (or service) or process, a new marketing method or a new organizational method in economic practice, workplace organization or the environment.

From a technical point of view, the products are also divided into complex and simple. The composite product is a product which consists of many parts which can be replaced in such a way that the product can be dismantled and reassembled (Directive 98/71/EC, Article 1 (c)). Products that do not meet the above characteristics should be considered as simple.

The Oslo Manual adopts three dimensions of diffusion of innovation. The minimum requirement for innovation is to implement a solution at enterprise level. In addition, innovations are on the market and in the world (international) scale.

On the other hand, the innovativeness of the company can be understood as the tendency and the ability of the company to implement innovations (Michalski, 2014, p. 78; Kraśnicka, 2013, pp. 167-168; Pichlak, 2012, p. 36; Nowacki, 2010, p. 30). Research shows that the degree of innovation depends on many factors and conditions both on the business side and on the external environment (Napiórkowski, 2014, pp. 15-16; Wiśniewska, 2014, p. 235; Michalski, 2014; Szopik-Depczyńska, Depczyński, 2012, p. 375). Mikołajczyk (2013, p. 237) also points to innovation factors particularly relevant for SMEs, such as: innovation readiness, employee input, high engagement and initiative, full knowledge of contractors, quick and short decision paths.

The literature gives many measures of the degree of innovation of the organization. A very good overview of these measures is given by Salavou (2004, p. 35). The most commonly used measures are: time needed to implement innovation, dichotomous variable - demonstrates the implementation or non-implementation of innovation, R\&D spending, economic value of innovations, the number of innovations adopted by the company from the list of innovations, and subjective measures. The selection of the latter depends on the context of the study. 


\section{Method}

During the period of the ROPW (2007-2015) the number of registered SMEs in Wielkopolska increased from almost 351,8 to over 409,4 thousand (GUS, online). During this period, SMEs submitted a total of 5661 applications for co-financing of investment projects. A total of 11 competition proceedings were held (Sprawozdanie WRPO..., pp. 268-269). The companies implemented 1479 projects, of which 255 (17.2\% of the number of implemented projects) were covered by the research in regard with innovation: 164 projects implemented by microcompanies operating on the market for no longer than two years (Action 1.1, Scheme I), 59 projects executed by other SMEs (Action 1.2, Scheme I) and 32 highly worldwide innovative projects (Action 1.2, Scheme III). Table 1 shows the basics of aid under the indicated actions and schemes. The innovativeness of the examined projects was assessed on the basis of several criteria differentiated in cross-sections of activities and schemes (Table 2). These criteria were used during competition proceedings.

Table 1. Criteria for assessing innovativeness of the examined investment projects

\begin{tabular}{|c|c|}
\hline Assessment criteria & Score range \\
\hline 1 & 2 \\
\hline \multicolumn{2}{|l|}{ Action 1.1 (Scheme I) } \\
\hline $\begin{array}{l}\text { Technically refined product/service offered by the applicant as a result of the project: } \\
\text { - lack of refined product/service }-0 \text { points, } \\
\text { - improved product/service }-2 \text { points }\end{array}$ & $0 / 2$ \\
\hline $\begin{array}{l}\text { Technically new product/service offered by the applicant as a result of the project: } \\
\text { - no new product/service }-0 \text { points, } \\
\text { - new product/service }-4 \text { points }\end{array}$ & $0 / 4$ \\
\hline $\begin{array}{l}\text { The project includes innovative technological and/or product and/or organizational solutions: } \\
\text { - lack of innovation - } 0 \text { point, } \\
\text { - at the enterprise scale - } 1 \text { point, } \\
\text { - in the voivodship scale (applied for less than } 5 \text { years) }-2 \text { points, } \\
\text { - in the country (applied for less than } 5 \text { years) - } 3 \text { points } \\
\text { (points are awarded for the level of innovation of particular elements, the higher level of innovation of a given element eliminates } \\
\text { the lower level, the beneficiary can receive a maximum of } 9 \text { points) }\end{array}$ & $0-9$ \\
\hline The project assumes the use of information and communication technologies (ICTs) in the enterprise & $0 / 2$ \\
\hline \multicolumn{2}{|l|}{ Action 1.2 (Scheme I) } \\
\hline $\begin{array}{l}\text { Number of new products/services proposed by the applicant resulting from the project. } \\
\text { 1. Improved product in terms of technology }-1 \text { point. } \\
\text { 2. Technically advanced product }-2 \text { points. } \\
\text { 3. New product straight from the technological point of view }-2 \text { points. } \\
\text { 4. New technologically complex product }-3 \text { points. } \\
\text { 5. No product/service }-0 \text { points. } \\
\text { 6. With the introduction of two new and more. } \\
\text { 7. The Beneficiary will receive a maximum of } 6 \text { points }\end{array}$ & $0-6$ \\
\hline $\begin{array}{l}\text { The number of new enterprise-level technologies applied by the operator as a result of the project. } \\
-1 \text { enhanced technology }-1 \text { point, } \\
-2 \text { and more upgraded technologies }-2 \text { points, } \\
\text { - introduction of } 1 \text { new technology }-2 \text { points, } \\
\text { - introducing } 2 \text { or more new technologies }-3 \text { points, } \\
\text { - no new/improved technologies }-0 \text { points. } \\
\text { With the introduction of two or more new technologies, the Beneficiary will receive a maximum of } 3 \text { points }\end{array}$ & $0-3$ \\
\hline
\end{tabular}


The project includes innovative solutions in terms of technological innovation, process and/or product innovation and/or organization and management, or applied for less than 5 years in the voivodeship or country:

- lack of innovation 0 points,

- on the scale of the enterprise 2 points,

- on the scale of the voivodship 3 points,

- in the country scale 4 points

(for the innovative solution of each element, the higher level of innovation of a given element eliminates the lower level.

The beneficiary can receive a maximum of 12 points)

\begin{tabular}{ll}
\hline The project involves the use of information and communication technologies (ICTs) in the enterprise & $0 / 2$ \\
\hline The project involves the use of know-how, knowledge - non patented solutions or patent, license & $0 / 4$ \\
\hline As a result of the project implementation, the R\&D department will be established or expanded (for own needs) & $0 / 2$ \\
\hline
\end{tabular}

As a result of the project implementation, the R\&D department will be established or expanded (for own needs)

Action 1.2 (Scheme III)

The project assumes the application of new technological solutions applied in the world for a period not exceeding 1 year

Technically refined product/service offered by the applicant as a result of the project:

- lack of refined product/service -0 points,

- improved product/service -2 points

Technically new product/service offered by the applicant as a result of the project:

- no new product/service -0 points,

- new product/service -4 points

The project involves the use of information and communication technologies (ICTs) in the enterprise

Applicant holds: patent for invention or protection for utility model or the right of registration of an industrial design or the right of registration of topographies of integrated circuits used in a new investment

Source: based on WRPO (2015), pp. 5-21.

\section{Results}

\section{Subject of the examined projects}

Overall, most projects were related to the production of wooden products and furniture, medical practice and printing activities. A dozen projects were implemented in five other sections of Polish Classification of Activities (Figure 1).

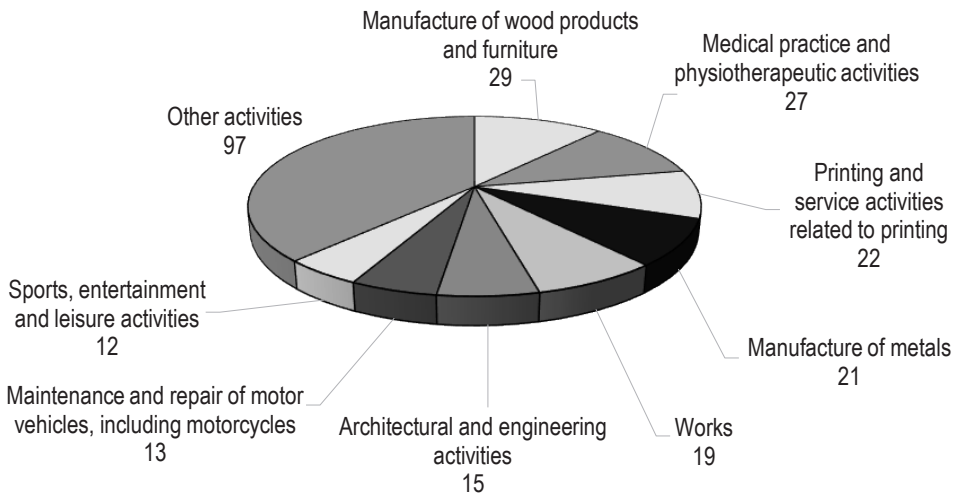

Figure 1. Number of projects included in the survey according to the Polish Classification of Activities

Source: based on the examined projects. 
Table 2. Principles of financial assistance of ROPW 2007-2013 under selected actions and schemes

\begin{tabular}{|c|c|c|c|c|}
\hline $\begin{array}{c}\text { Action } \\
\text { and scheme }\end{array}$ & Subject od assistance & Financial allocation (euro) & $\begin{array}{l}\text { Ceiling of eligible } \\
\text { costs }\end{array}$ & $\begin{array}{l}\text { Co-financing amount and other restrictions } \\
\text { (PLN) }\end{array}$ \\
\hline Action 1.1. & & $\begin{array}{l}\text { - ERDF (European Regional } \\
\text { Development Fund) }-14,220 \mathrm{mln}, \\
\text { - state budget }-2,234 \mathrm{mln}, \\
\text { - private funds - } 11,153 \mathrm{mln}\end{array}$ & $\begin{array}{l}-60 \% \\
-40 \% \text { for } \\
\text { companies in the } \\
\text { transport sector }\end{array}$ & $\begin{array}{l}\text { - minimum amount of funding }-9,000 \\
\text { - maximum amount of funding }-200,000\end{array}$ \\
\hline Action 1.2 & $\begin{array}{l}\text { Purchase of fixed assets } \\
\text { and intangible assets }\end{array}$ & \multirow{3}{*}{$\begin{array}{l}\text { - ERDF - } 171,470 \mathrm{mln} \\
\text { - state budget - 9,200 mln, } \\
\text { - privet funds - 134,487 mln }\end{array}$} & \multirow{2}{*}{$\begin{array}{l}\text { - } 60 \% \text { for micro and } \\
\text { small businesses, } \\
-50 \% \text { for medium- } \\
\text { sized companies, } \\
-40 \% \text { for } \\
\text { companies in the } \\
\text { transport sector }\end{array}$} & $\begin{array}{l}\text { Minimum co-financing: } \\
\text { - microenterprises (operating for no more } \\
\text { than } 2 \text { years) - } 400,000 \text {, } \\
\text { - micro- (operating for more than } 2 \text { years), } \\
\text { small and medium-sized enterprises } \\
-9,000 \text {, } \\
\text { - microenterprises in rural areas - over } \\
300,000 \text {, } \\
\text { Maximum amount of funding: } \\
\text { - All companies - } 1.2 \mathrm{mln}\end{array}$ \\
\hline Scheme III & $\begin{array}{l}\text { Acquisition and } \\
\text { application of new } \\
\text { technologies applied in } \\
\text { the world for not more } \\
\text { than } 3 \text { years }\end{array}$ & & & $\begin{array}{l}\text { Maximum eligible costs }-8 \mathrm{mln} \text {, } \\
\text { Minimum amount of funding: } \\
\text { - all companies }-9,000 \text {, } \\
\text { - microenterprises in rural areas - over } \\
300,000 \text {, } \\
\text { Maximum amount of funding: } \\
\text { - all companies - } 4 \mathrm{mln} \\
\text { - transport companies - } 3.2 \mathrm{mln}\end{array}$ \\
\hline Scheme IV & $\begin{array}{l}\text { Purchase of fixed assets } \\
\text { and intangible assets } \\
\text { under de minimis aid }\end{array}$ & & $70 \%$ & $\begin{array}{l}\text { Minimum co-financing: } \\
\text { - all companies - over } 200,000 \text {, } \\
\text { - microenterprises in rural areas - over } \\
300,000 \text {, } \\
\text { Maximum amount of funding: } \\
\text { - all companies - } 500,000 \text {, } \\
\text { - companies in the transport sector } \\
\text { - } 350,000\end{array}$ \\
\hline
\end{tabular}

Source: own elaboration based on: WRPO (2009), pp. 27-51.

In terms of activities and schemes, the classification of projects in regard with the subject was slightly different. Within the framework of activity 1.1 , there were mainly projects of medical practice (22 projects), including dental practice (9 projects). Within the action 1.2, scheme I the projects mainly concerned the production of furniture and wooden products (17 projects). Among the most technologically advanced projects (activity 1.2, scheme III), printing and printing services ( 8 projects) and plastics (6 projects) were dominant.

\section{New and improved products}

Companies have introduced 667 new and improved products and services. On average, there were 2.6 products per project. Most of the products were introduced by micro-enterprises operating on the market for no longer than two years (Table 3). Companies implementing projects under measure 1.2, scheme I introduced 173 products, and companies performing the most technologically advanced projects -91 products. The research also shows that more services than products were introduced to the market, with more new ones than improved ones. 
Table 3. Number of products placed on the market by the examined projects

\begin{tabular}{lcccrc}
\hline \multicolumn{1}{c}{ Action/scheme } & Improved product & New product & Improved service & New service & Total \\
\hline 1.1 (Schemet I) & 17 & 48 & 119 & 219 & 403 \\
1.2 (Scheme I) & 31 & 86 & 9 & 47 & 173 \\
1.2 (Scheme III) & 44 & 25 & 16 & 6 & 91 \\
\hline Total & 92 & 159 & 144 & 272 & 667 \\
\hline
\end{tabular}

Source: based on the examined projects.

For projects implemented under Action 1.2, scheme I, it was able to distinguish between complex and simple products (Table 2). The obtained data show that for 173 products only four were simple, including three new products and one improved product. New simple products were noted in the carpentry project, and the improved product was improved in the construction industry. In contrast, the projects under study did not include simple services.

\section{Difilusion of innovation}

The examined projects were evaluated from the point of view of the type and scope of applied innovations, but the projects implemented under scheme III were only assessed from the point of view of technological innovation. It was necessary to apply innovation that exists in a global scale for no longer than a year. Applicants were obliged to attach the special innovation opinion from a relevant scientific or research institution. Table 4 shows the breakdown of the number of examined projects by type and extent of innovation.

Table 4. Breakdown of the total number of examined projects from the perspective of innovative solutions

\begin{tabular}{lcccr}
\hline \multicolumn{1}{c}{ Innovation } & Product & Process & Organizational & Total \\
\hline Company (scheme I) & 93 & 11 & 169 & 273 \\
Region (scheme I) & 17 & 10 & 7 & 34 \\
State (scheme I) & 113 & 202 & 47 & 362 \\
World (scheme III) & - & 32 & - & 32 \\
\hline Total & 223 & 255 & 223 & 669 \\
\hline
\end{tabular}

Source: based on the examined projects.

The table shows that the projects implemented under Scheme I were mainly characterized by technological and product innovativeness at national level, while by organizational level - at enterprise level. Significant differences in innovativeness are seen, however, between the projects implemented under Action 1.1 and Action 1.2. In the first group there was a strong correlation between product and process innovations. The application of innovative technology at national level enabled the introduction of innovative products on a national, regional and enterprise scale. Technological innovation at the regional level has generally translated into regional product innovation. Only one project, under Action 1.1 and in clothing production, recorded an innovative product at the company level, but no innovation products were produced nationally. Finally, innovative technology at the enterprise level has enabled innovative products to be created mostly at the scale of the enterprise. Only one project, under Action 1.1 and in 
medical device production, was reported, where the application of innovative technology at the enterprise level enabled the launch of an innovative product on a regional scale.

The overwhelming organizational innovation at the enterprise level can be justified by the fact that the examined projects were implemented by the relatively new micro-enterprises. These were often single operators, had no extensive organizational structure and did not report the need for advanced organizational and management methods. Only three examined projects included organizational solutions at national level (conservation services, printing and building services) and one at regional level (non-contact car wash). For the projects implemented under Action 1.2, Scheme I, there was a close link between technological, product and organizational innovation at national level. Of the 59 projects covered by the survey, 47 were characterized by product innovation at national level, 52 - by technological innovation at national level, and 44 - by organizational innovation at this level. Organizational innovation is due to the fact that in this group of applicants were small and medium-sized businesses, which due to their scale of activity needed more advanced and innovative solutions in terms of management, production organization, sales and marketing.

The research projects also confirm the close relationship between product innovation and technology in terms of the degree of their advancement (novelty or improvement). Only in one project (in the construction industry) the application of two upgraded technologies at the regional level contributed to the creation of three new complex services at this level. In the case of other projects, new technologies have contributed to the emergence of new or improved products, and improved technologies - only for improved products. Taking into account the number of technologies, there were 120 new technologies and 6 improved technologies in 59 projects.

\section{Other measures of innovation}

The innovation of the projects was measured by additional criteria, which varied in cross-sections of activities and schemes (Table 5). The following table shows the number of projects that provide additional solutions for the innovativeness of projects and their implementing companies.

Table 5. Number of projects containing additional innovative solutions

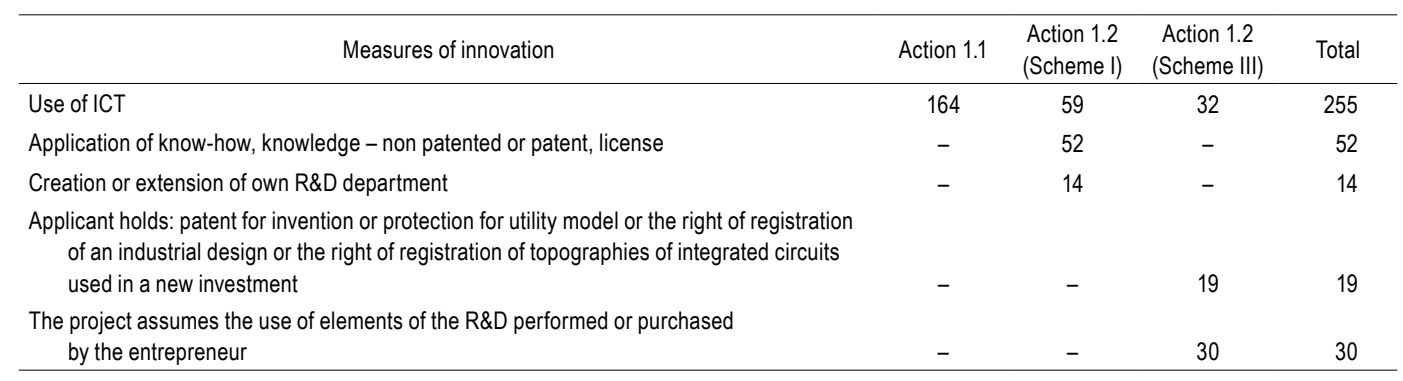

Source: based on the examined projects.

Table 5 shows that all the projects under investigation assumed the use of ICT. In the vast majority of projects it was the purchase and installation of computer software for accounting and design. Due to the high frequency of ICT changes in the market, this software has always been the latest. Most of the projects implemented under Action 1.2, Scheme I, were planned for the use of intangible assets indicated in Table 5, but it should be emphasized 
that the entrepreneurs to meet this criterion and get additional points often used the licenses sold together with computer software. It is also worth emphasizing that in several projects entrepreneurs have skillfully described the way they use non-patented knowledge (know-how). On the other hand, in relatively few projects entrepreneurs planned to create a R\&D department for their own needs. This was due to the fact that the creation of the R\&D department was associated with higher costs and the employment of additional people in the research facilities. In most of the high innovative projects, the use of patents and protection rights was planned, and almost all projects assumed the purchase or use own $R \& D$ results.

\section{Conclusions}

The paper analyzes the innovativeness of a selected group of projects implemented by SMEs within the framework of the ROPW 2007-2013. The degree of innovation was assessed on the basis of selected criteria used in the competition procedures. These criteria very well reflect the measures commonly recommended in the literature of the subject.

The number of registered SMEs in Wielkopolska and the number of applications for co-financing show, however, that entrepreneurs were not particularly interested in EU grants. Taking into account the average number of registered companies in the years 2007-2015 (slightly over 360.6 thousand), applications were submitted by less than $1.5 \%$ of these companies, and the projects realized $-0.4 \%$. The analyzed program did not significantly influence the degree of innovation of the whole sector of SMEs in Wielkopolska region. There are a number of reasons for poor interest in grants, although no further research has been done in this area. Formal restrictions (such as lack of arrears in taxes and social security contributions, exclusion from any court proceedings), small amounts of funding, reimbursement rules, or maintenance of the project's sustainability for 3 years are indicated.

On the other hand, the degree of innovation of the projects included in the survey has to be considered as high. Entrepreneurs launched 667 products, most of which were new services and products. Although only Action 1.2 (Scheme I) has formally distinguished simple and complex products, yet in other activities and schemes we also deal mainly with complex products.

More than half of the projects were characterized by innovative solutions at national level. Technological and product innovation were predominant. Organizational innovation dominated at enterprise-level solutions. The research also confirmed the close dependence of product innovation on technological innovation. The vast majority of projects implemented within the framework of actions and schemes met satisfactorily additional criteria of innovation (ICT, intangible assets, R\&D).

\section{References}

Directive 98/71/EC of the European Parliament and of the Council of 13 October 1998 on the legal protection of designs, OJ L 289.

European Union (2014). Enterprise. Topics of The European Union. Retrieved from: http://europa.eu/pol/index_en.htm.

GUS (2017). Bank danych lokalnych. Retrieved from: https://bdl.stat.gov.pl/BDL/start.

Kraśnicka, T. (2013). Innowacyjność przedsiębiorstw - uwarunkowania organizacyjne. Studia Ekonomiczne. Zeszyty Naukowe Uniwersytetu Ekonomicznego w Katowicach, 136, 165-179,

Michalski, E. (2014). Czynniki determinujące innowacyjność przedsiębiorstwa. Handel Wewnętrzny, 6 (353), 78-87.

Mikołajczyk, B. (2013). Pomiar i ocena innowacyjności MSP. Zarządzanie i Finanse, 2 (cz. 2), 265-279,

Napiórkowski, J. (2014), Charakterystyka podstawowych pojęć. In: J. Napiórkowski (ed.), Techniczne podstawy innowacyjności. Olsztyn: Uniwersytet Warmińsko-Mazurski w Olsztynie. 
Nowacki, R. (2010). Zarządzanie - konkurencyjność - innowacyjność. In: R. Nowacki (ed.), Innowacyjność w zarządzaniu a konkurencyjność przedsiębiorstwa. Warszawa: Difin.

Oslo Manual (2005). Guidelines for collecting and interpreting innovation data. European Commission, $3^{\text {rd }}$ edition.

Pichlak, M. (2012). Uwarunkowania innowacyjności organizacji. Studium teoretyczne i wyniki badań. Warszawa: Difin.

Salavou, H. (2004). The Concept of Innovativeness: Should we Need to Focus? European Journal of Innovation Management, 7 (1), 33-44.

Sikora, J., Uziębło, A. (2017). Innowacja w przedsiębiorstwie - próba zdefiniowania. Retrieved from: http://zif.wzr.pl/pim/2013_2_2_27. pdf.

Sprawozdanie WRPO (2017). Sprawozdanie końcowe z wdrażania Wielkopolskiego Regionalnego Programu Operacyjnego na lata 2007-2013, Instytucja Zarządzajaca Wielkopolskim Regionalnym Programem Operacyjnym na lata 2007-2013. Retrieved from: http://wrpo2007-2013.wielkopolskie.pl/index.php/wrpo-informacje/sprawozdania-z-realizacji-wrpo183.

Szopik-Depczyńska, K., Depczyński, R. (2012). Aktywność innowacyjna sektora małych i średnich przedsiębiorstw (MŚP) w aspekcie konkurencyjności przedsiębiorstw. Studia i Prace Wydziału Nauk Ekonomicznych i Zarządzania, 25, 373-391.

Wiśniewska, A.M. (2014). Wpływ sytuacji finansowej MSP na rozwój gospodarczy województwa mazowieckiego. In: T. Kamiński, O. Charucka (eds.), Sektor finansów w rozwoju gospodarczym kraju - dylematy, kierunki zmian, cz. II. Warszawa: Akademia Finansów i Biznesu Vistula.

WRPO (2009). Wielkopolski Regionalny Program Operacyjny na lata 2007-2013. Szczegółowy opis priorytetów programu operacyjnego, Poznań, kwiecień.

WRPO (2015). Kryteria Wyboru Projektów w ramach Wielkopolskiego Regionalnego Programu Operacyjnego na lata 2007-2013, Urząd Marszałkowski Województwa Wielkopolskiego, Poznań, marzec.

Cite this article aS: Cieślukowski, M. (2018). Impact of Regional Operational Program for Wielkopolskie Voivodeship 2007-2013 on innovation of micro, small and medium enterprises in Wielkopolska region. European Journal of Service Management, 3 (27/2), 95-103. DOI: 10.18276/ejsm.2018.27/2-12. 